\title{
Acknowledgments
}

This book would not have been possible without the financial support of the Social Sciences and Humanities Research Council of Canada. I am grateful for their sustained funding. Additionally, the Office of Research Services at York University, and specifically Janet Friskney, have been very helpful in securing grants for this project.

I am appreciative of the welcoming and accommodating staff at several institutions that have allowed me access to their archives: The Berg Collection, New York Public Library; the Special Collections of the Sussex University Library for several visits to consult the Monks House Papers and the Leonard Woolf Archive; the British Library Sound Archives; and the Special Collections Archives of the Hogarth Press at the University of Reading. I am grateful to Kirby Smith, Senior Library Assistant, and Thomas Birkhead, Library Assistant, Penguin Random House Archive, UK; Sarah Baxter, Contracts Advisor and Literary Estates, The Society of Authors; and David Plant, the Random House Project Officer at the Hogarth Press Archives for permission to view several files at the Archives of the Hogarth Press. Scott Libraries at York University, especially the RACER Interlibrary Loan staff, have expeditiously helped me with countless hard-to-find materials over the years.

I have also learned more than I can say from several significant and generous mentors, friends, and colleagues, first and foremost Lesley J. Higgins, whose guidance, inspiration, and erudition has fed this project from its inception. I am fortunate to have had the long-standing support and encouragement of Marie-Christine Leps, Leslie Sanders, Gail Vanstone, Lisa Ossowski, Tanya Sweeney, Alison Halsall, Cheryl Cowdy, Candida Rifkind, and Natalie Neill. A special thank you concerning this publication goes to Natalie for her expert indexing of the book, and to Kevin Karst for building my perfect writer's desk. I have had the good fortune to work with helpful research assistants; Kristen Ames and Stephen Van Andel did much proverbial legwork and 
acquired vital resources for me. My thanks also to Judith Williams for her knowledgeable copy editing and to Barb Porter for her kind, astute, and professional oversight, as well as to Richard Ratzlaff, Mark Thompson, and the anonymous readers at University of Toronto Press. Additionally, I have benefited greatly by the chance to present much of this work at conferences, including several papers at meetings of the Annual International Virginia Woolf Society, the Modernist Studies Association, and Performance Studies international.

Long before the completion of this book, my love of music and literature was shared with and fostered by instrumental people in my life. My mother, Roz, my father, Terry, and my sister, Shaleena - all of whom, in many ways, went on this journey of ideas with me - have unfailingly buoyed my life and my academic pursuits. I dedicate this book to them, and in the memory of my late father.

At the time of writing, only four of the Cambridge Editions of Virginia Woolf's novels were available: Mrs. Dalloway, The Waves, The Years, and Between the Acts. I have used these editions and supplemented the rest of Woolf's oeuvre with the Oxford Classics editions. While this book was in production, the Cambridge Editions of Night and Day and Orlando came out. At this late stage in the publication process I was unable to use them in the current manuscript.

\section{Permissions Credits}

The following permissions are gratefully acknowledged:

The unpublished transcription of the letter from Elizabeth Trevelyan to Virginia Woolf dated 1 September 1940 is reproduced courtesy of The Keep, Brighton, UK, and Philip Trevelyan.

The unpublished transcription of letters from Basil de Sélincourt to Virginia Woolf, one dated 26 October [1926] and one undated, are from The Random House Group Archive and reproduced courtesy of The Random House Group Ltd., the Library of The University of Reading, Special Collections, and Mary Lowe.

The unpublished letter from Leonard Woolf to Eric White dated 30 November 1927 is from The Random House Group Archive and Library of the University of Reading, Special Collections, and reproduced courtesy of The Random House Group Ltd., The University of Sussex, and The Society of Authors.

A revised version of my essay "Transforming Musical Sounds into Words: Narrative Method in Virginia Woolf's The Waves," Narrative 13.2 (May 2005): 160-81, is reproduced here by permission of The Ohio State University Press. 